\title{
Considerations about the recommendations of the Commission on the Limits of the Continental Shelf on the Amazon fan ${ }^{1}$
}

\author{
Considerações sobre as recomendações da Comissão de \\ Limites da Plataforma Continental sobre o cone do Amazonas
}

http://dx.doi.org/10.1590/0034-7329201400107

RODRIGO FERNANDES MORE*

Rev. Bras. Polít. Int. 57 (1): 117-142 [2014]

\section{Introduction}

In 2004 Brazil presented before the Commission on the Limits of the Continental Shelf (CLCS) its Submission to the Brazilian continental shelf outer limit, in accordance with article 76 of the 1982 United Nations Convention on the Law of Sea (UNCLOS 1982, hereinafter just UNCLOS) ${ }^{2}$. The objective was to define the new limits of the Brazilian continental shelf beyond the 200 nautical miles $^{3}$ from the baselines from which the breadth of the territorial sea is measured, an addition of approximately $965,000 \mathrm{~km}^{2}$.

\footnotetext{
1 This article is dedicated to Professor Vicente Marotta Rangel in celebration of his 90th birthday. The author thanks the comments from the Commander (Ret.) Luiz Carlos Torres, the Commander Izabel King Jeck and the Lieutenant Commander Ana Angélica Ligiero Alberoni Tavares, all of them from the Brazilian Continental Shelf Survey Project-Plano de Levantamento da Plataforma Continental Brasileira (LEPLAC). However, some possible errors or omissions are the entirely responsibility of the author, and do not necessarily reflect the position of the LEPLAC Project or Brazilian Government.

* Federal University of São Paulo (Unifesp), São Paulo, SP, Brazil (more.unifesp@gmail.com).

2 The UNCLOS entered into force internationally in November 16, 1994. Decree no. 1,530, dated June 22, 1995, declares the entry into force for Brazil at that same date. As a matter of fact, the UNCLOS were promulgated by Brazil through Decree 99,165, dated March 12, 1990 (Official Gazette of March 13, 1990), but the UNCLOS were not in force yet. Then, the mentioned decree was revoked by Decree no. 99,263, dated May 24,1990 , under the argument that the revoked decree "...opens a legislative gap with relation to the Brazilian maritime spaces" (from the original in a free author's translation: "...Decreto no 99.165 , de 12 de março de 1990, abre lacuna legislativa com relação aos espaços marítimos brasileiros"). In 1991, this revoking decree has also been revoked by Decree dated Septermber 5, 1991 (Official Gazette of September 6, 1991). Considering that repristination is not applicable because of the terms of Decree no. 1,530/1995, the date of entry into force of UNCLOS to Brazil is November 16, 1994. However, the UN non-official version in Portuguese of UNCLOS for Brazil remains that attached to Decree no. 99,165.
}

3 According to the International Hydrographic Bureau (IHB) in 1929, the international nautical mile is a unit of length defined as follows: $1 \mathrm{M}=1,852 \mathrm{~m}$. Then, 200 nautical miles correspond to $370.4 \mathrm{~km}$. (CLCS 1999, 25). 
Comparatively, considering the total official area of Brazil of 8,515,767,049 km² (IBGE 2010), this addition corresponds to $11 \%$ of the national territory, or the summed up area of 13 states: Acre, Alagoas, Ceará, Espírito Santo, Paraíba, Paraná, Pernambuco, Rio de Janeiro, São Paulo, Sergipe, Paraná, Santa Catarina, and Distrito Federal. Almost the same of Egypt $\left(1,001,049 \mathrm{~km}^{2}\right)$ and a little bigger than Venezuela $\left(912,015 \mathrm{~km}^{2}\right)$.

In April 2007, the CLCS delivered its recommendations to Brazil about the outer limits proposed. A summary of the Recommendations was disclosed by CLCS on August 24, 20114, which includes restrictions of approximately $19 \%$ of the total demanded area (approximately $200,000 \mathrm{~km}^{2}$, or the area equivalent to the states of Rio de Janeiro, Espírito Santo and Santa Catarina, or two times the area of Portugal, 92,152 $\mathrm{km}^{2}$ ), more precisely about four areas: a) the Amazon Fan; b) the North Brazilian Ridge; c) the Vitória-Trindade Ridge; and d) the São Paulo Plateau and Meridional Continental Margin, even though the limits of approximately $765,000 \mathrm{~km}^{2}$ were recommended as the continental shelf of Brazil 5 .

In view of the partial success of Brazilian demand, since July 2008, a review of the Brazilian submission is being prepared by the Brazilian Continental Shelf Survey Project-Plano de Levantamento da Plataforma Continental Brasileira (LEPLAC)—, as allowed by article 8 of Annex II of the UNCLOS.

The proposal of this article, supported by the interdisciplinarity required by the theme, is to present the main aspects of the controversy between Brazil and the CLCS about the Amazon Fan, limited to the analysis of the summary of Recommendations on the Brazilian Submission disclosed by CLCS, since the full recommendations received by Brazil, as well as 12 of the 18 recommendations already done by CLCS, remain confidential ${ }^{6}$.

Thus, the first section introduces the CLCS and its characteristics. The second section addresses the fundaments of the continental shelf extension beyond the 200 nautical miles. In the third section, we will present the controversies between CLCS and Brazil about the Amazon Fan, based on the recommendations from CLCS. In the fourth section, we will briefly outline considerations about the Brazilian alternatives, between a new and a revised submission. We will conclude with brief final reflections with the aim of starting the legal debate about the

4 The Summary of recommendations was approved by the CLCS on August 24, 2011, and only this document was disclosed to the public to date.

5 The consultation to these areas and to other maps of the coastal and oceanic zones of Brazil can be done in the Geographic Atlas of Coastal and Oceanic Zones of Brazil (IBGE 2013) and in the website of the Secretariat of the Interministerial Commission on the Resources of the Sea, available at <http://www.mar.mil.br/secirm/>, accessed March 10, 2014.

6 The recommendations are disclosed by CLCS through "executive summaries." Only five recommendations- to Ireland (2007), Australia (2008), Mexico (2009), Philippines (2012), and Barbaros (revised, 2012)—are available in full version under previous authorization of submitting coastal State. The remaining 13 recommendations (including the Brazilian one) are available only on their executive summaries version. The recommendations in full or summarized, a complete list of countries that presented submissions before the CLCS and other documents submitted by the coastal States can be consulted in: UNITED NATIONS. Division for the Ocean Affairs. Available at <http://www.un.org/depts/los/clcs_new/commission_submissions.htm>, accessed February 25, 2014. 
scientific, technical and legal sufficiency of the Brazilian arguments for the extension of the continental shelf in the Amazon Fan, to justify and reinforce the original Brazilian Submission before the CLCS.

\section{The Commission on the Limits of the Continental Shelf (CLCS)}

The CLCS was created by article 76, paragraph 8 of the UNCLOS aiming to allow, from the legal viewpoint, the implementation of technical rules for the extension of the continental shelf limits beyond the 200 nautical miles. It is noteworthy, and this topic will be relevant in the development of this study, that the technical criterion (i.e. geological, geophysical, hydrographic, oceanographic) is subsidiary to the legal criterion, the latter represented by the UNCLOS itself, and by the legal limits it establishes, also in regard to the competences and functions of the CLCS.

According to article 3 of Annex II of the Convention, the functions of CLCS are as follows:

(a) to consider the data and other material submitted by coastal States concerning the outer limits of the continental shelf in areas where those limits extend beyond 200 nautical miles, and to make recommendations in accordance with article 76 and the Statement of Understanding adopted on 29 August 1980 by the Third United Nations Conference on the Law of the Sea;

(b) to provide scientific and technical advice, if requested by the coastal State concerned during the preparation of the data referred to in subparagraph (a).

In performing such functions, the CLCS might:

cooperate, to the extent considered necessary and useful, with the Intergovernmental Oceanographic Commission of UNESCO, the International Hydrographic Organization and other competent international organizations with a view to exchanging scientific and technical information which might be of assistance in discharging the Commission's responsibilities. (UNCLOS, Annex II, art. 3, paragraph 2).

The UNCLOS has defined as deadline for the establishment of the CLCS 18 months after the date of entry into force of the Convention (May 16, 1995), but in the fourth meeting of the Parties to the Convention in 1995, the deadline was consensually extended to March 1997 (UNCLOS 1996, paragraph 2, p. 3).

The CLCS first session was held between July 16 and 20, 1997, from the beginning with the participation of the Brazilian expert Alexandre Tagore Medeiros de Albuquerque, a retired commander of the Brazilian Navy, who has performed with honor this function until his decease in 2011. 
In brief, the CLCS is a technical body formed by

21 members who shall be experts in the field of geology, geophysics or hydrography, elected by States Parties to this Convention from among their nationals, having due regard to the need to ensure equitable geographical representation, who shall serve in their personal capacities. (Annex II of the UNCLOS, article 2)

The experts are divided into Subcommissions to appraise the submissions, with seven experts for each Subcommission, so that the experts can participate in more than one Subcommission; however, rules shall be observed to avoid experts who are nationals of the submitting State, as well as, insofar as possible, there should be a scientific and geographic balance among the experts of each Subcommission (CLCS 2008c, Rule 42).

Among the main documents of the CLCS, there are the Rules of Procedure (CLCS 2008c) and the Scientific and Technical Guidelines of the Commission on the Limits of the Continental Shelf (CLCS 1999), hereinafter referred only as Guidelines.

The CLCS ordinarily gathers in two periods of the year, at the headquarters of the United Nations in New York. The current Brazilian expert in the CLCS is the rear admiral (Ret.) Jair Alberto Ribas Marques, who has coordinated the LEPLAC.

The CLCS answer to a coastal State submission for the extension of the continental shelf beyond the 200 nautical miles is called "recommendation," a terminology that deserves a brief comment, since it is the product of an effort to find a legal term compatible to an ipso facto and ab initio existing sovereignty right. In a recent article, More (2012, 65-66) says:

The recommendation of the CLCS on Extended Continental Shelf (ECS), made definitive after the request of revision or the new submission, is legally binding on the coastal State, pursuant to article 76, paragraph 8 of the UNCLOS. According to the system, the request, before the CLCS, aims to recognize the preexisting sovereignty on the ECS, with ex tunc effects about the performance of a "ipso facto" and "ab initio" existing right of the State, and, therefore, from which rights and responsibilities are derived, with no restriction at all in the general international law.

This is why International Seabed Authority (ISA) does not bind the rights of sovereignty on the continental shelf to the establishment of the ECS:

This section shows how the implementation of Article 82 of the Convention relates to the continental shelf regime. Article 77 of the Convention provides coastal States with sovereign rights over the continental shelf, for the purpose of exploring and exploiting its natural resources. The sovereign rights of the 
coastal States over the continental shelf exist ab initio and ipso jure regardless of the extent of the continental shelf and regardless of the establishment of the outer limits of the continental shelf beyond 200M. They are exclusive and do not depend on effective or notional occupation or on any express proclamation. Therefore, a coastal State is entitled to exercise those rights even before the limits are final and binding. In other words, the extraction of resources from the OCS (which would in turn trigger the implementation of Article 82) is not contingent on the delineation of the outer limits of the continental shelf beyond $200 \mathrm{M}^{7}$

There is a necessary repair to this statement, in its initial part: definitive and binding are the limits fixed for the continental shelf on the basis of the recommendations, not the recommendation itself. The consequence is that if a State does not agree with the recommendations, it will not be possible to deposit before the UN General Secretary the non-recommended limits. With this in mind, the position of Silva $(2013,114)$ about the interpretation of paragraph 8 , article 76, of the UNCLOS (“...but does not prevent such State from fixing different limits of those appointed by the final and binding recommendations of (LCS”) ${ }^{8}$ deserves a new reflection.

\section{Fundaments for the extension of the Continental Shelf beyond the 200 nautical miles}

The legal fundaments for the extension of the continental shelf beyond the 200 nautical miles are particularly two-the UNCLOS and the Guidelines, not forgetting the government by other general rules of the international law, such as the 1969 Vienna Convention on the Law of Treaties. In the case highlighted in this study, the CLCS recommendations on the Amazon Fan, we will take as argument the two main legal fundaments.

7 Author's free translation from original: "A recomendação da CLPC sobre a PCE, tornada definitiva depois do pedido de revisão ou nova submissão, é juridicamente vinculante ao Estado costeiro, de acordo com o artigo 76, $\$ 8$ da CNUDM. Segundo o regime, o pleito, perante a CLPC, tem como objeto o reconhecimento de soberania pré-existentes sobre a PCE, com efeitos ex tunc acerca do exercício de um direito do Estado costeiro existente ipso facto e ab initio e, portanto, do qual decorrem direitos e responsabilidades, sem qualquer restrição no direito internacional geral. É por essa razão que a ISA não vincula os direitos de soberania sobre a plataforma continental ao estabelecimento da PCE24 (tradução nossa): Esta seção demonstra como a implementação do artigo 82 da Convenção relaciona-se com o regime da plataforma continental. $\mathrm{O}$ artigo 77 da Convenção confere aos Estados costeiros direitos de soberania sobre a plataforma continental, com objetivo de exploração e explotação de seus recursos naturais. Os direitos de soberania dos Estados costeiros sobre a plataforma continental existe ab initio e ipso jure a despeito da extensão da plataforma continental e a despeito do estabelecimento dos limites exteriores da plataforma continental além das 200 milhas. Eles são exclusivos e não dependem de ocupação efetiva ou fictícia ou de qualquer declaração expressa. Assim, um Estado costeiro está investido do direito de exercer tais direitos, mesmo antes dos limites se tornarem defi nitivos e vinculantes. Em outras palavras, a extração de recursos da PCE (que pode se tornar o gatilho para implementação do artigo 82) não depende do delineamento dos limites externos da plataforma continental além das 200 milhas."

8 Author's free translation from original: “... mas que não impedem que esse mesmo Estado fixe limites distintos dos preconizados pelas recomendaçôes 'definitivas e obrigatórias' da CLPC.” 


\section{UNCLOS}

The legal concept of the continental shelf is presented in paragraph 1 , article 76 of the UNCLOS, and reflected in article 11 of Brazilian Law no. 8,617/1993, as seen in Table 1:

Table 1. Comparison of UNCLOS with Brazilian Law no. 8,673/1993.

\subsection{UNCLOS art. 76, paragraph 1}

The continental shelf of a coastal State comprises the seabed and subsoil of the submarine areas that extend beyond its territorial sea throughout the natural prolongation of its land territory to the outer edge of the continental margin, or to a distance of 200 nautical miles from the baselines from which the breadth of the territorial sea is measured where the outer edge of the continental margin does not extend up to that distance.

\section{Law no. 8,617/1993, art. 11}

The Brazilian continental shelf comprises the seabed and subsoil of the submarine areas that extend beyond its territorial sea throughout the natural prolongation of its land territory to the outer edge of the continental margin, or to a distance of 200 nautical miles from the baselines from which the breadth of the territorial sea is measured where the outer edge of the continental margin does not extend up to that distance.

Sole Paragraph. The outer limit of the continental shelf shall be fixed in compliance with the criteria defined in art. 76 of the United Nations Convention on the Law of Sea, agreed on Montego Bay, on December 10, $1982 .{ }^{9}$

\section{If the coastal State manages to demonstrate to the CLCS that the natural} extension of its territory towards the outer border of the continental margin goes beyond the distance of 200 nautical miles of the baselines [article 76, paragraph 4, (a)], then the continental shelf can be extended beyond this limit, respecting the geological criteria determined in paragraphs 4 to 6 , article 76 of the UNCLOS, according to four rules: two positive rules, also called "formulae," and two constraint rules.

This demonstration is called in the Guidelines "test of appurtenance" 10 (CLCS 1999, paragraph 2.2), which is not mentioned in the UNCLOS, nor in its Annex

9 Author's free translation from original: "Art. 11. A plataforma continental do Brasil compreende o leito e o subsolo das áreas submarinas que se estendem além do seu mar territorial, em toda a extensão do prolongamento natural de seu território terrestre, até o bordo exterior da margem continental, ou até uma distância de duzentas milhas marítimas das linhas de base, a partir das quais se mede a largura do mar territorial, nos casos em que o bordo exterior da margem continental não atinja essa distância. Parágrafo único. O limite exterior da plataforma continental será fixado de conformidade com os critérios estabelecidos no art. 76 da Convenção das Nações Unidas sobre o Direito do Mar, celebrada em Montego Bay, em 10 de dezembro de 1982."

10 The paragraphs 2.2.2 and 2.2.3 of the Guidelines present the CLCS definition to the term: "2.2.2. The Commission defines the term 'test of appurtenance' as the process by means of which the above provision is examined. The test of appurtenance is designed to determine the legal entitlement of a coastal State to delineate the outer limits of the continental shelf throughout the natural prolongation of its land territory to the outer edge of the continental margin, or to a distance of 200 nautical miles from the baselines from which the breadth of the territorial sea is measured where the outer edge of the continental margin does not extend up to that distance. 2.2.3. If a State is able to demonstrate to the Commission that the natural prolongation of its submerged land territory to the outer edge of its continental margin extends beyond the 200-nautical-mile distance criterion, the outer limit of its continental shelf can be delineated by means of the application of the complex set of rules described in paragraphs 4 to 10." (CLCS 1999, 12). 
II, but is recognized and admitted by the coastal State as applicable procedural rule in the submission for the extension of the continental shelf.

The formulae that allow the extension of the continental shelf beyond the 200 nautical miles depend on the determination of the so-called foot of slope (Jeck et al. 2012), a geology term defined by the points of "maximum change in the gradient," as determined by paragraph 4 (b), article 76 of the UNCLOS. It is the coastal State responsibility to demonstrate in its submission the position of the foot of slope, from which the alternative criteria will be applied; it is the responsibility of CLCS to examine the documents and evidences brought by the coastal State about such location, eventually showing alternatives in case of disagreement (CLCS, 1999, paragraph 2.1.13), which shall be based on the respect of general rules of the international law.

According to article 76, paragraph 4, items (i) and (ii) of the UNCLOS, the affirmative rules (or "formulae") are connected through an inclusive disjunction:

(i) a line delineated in accordance with paragraph 7 by reference to the outermost fixed points at each of which the thickness of sedimentary rocks is at least 1 per cent of the shortest distance from such point to the foot of the continental slope (known as Gardiner formulae); or

(ii) a line delineated in accordance with paragraph 7 by reference to fixed points not more than 60 nautical miles from the foot of the continental slope (known as Hedberg formulae) ${ }^{11}$

The paragraphs 2.1.5 and 2.1.6 of the Guidelines (CLCS 1999, 10) present the CLCS interpretation to the "formulae" rules:

2.1.5. The use of an inclusive disjunction as a connective between the two formulae implies that the compound is true so long as at least one of the components is true. Thus, the limit of the continental shelf can be extended up to a 1 per cent sediment thickness line delineated by reference to fixed points, or to a line delineated by reference to fixed points at a distance of 60 nautical miles from the foot of the continental slope, or both.

2.1.6. When both formulae lines are used, their outer envelope determines the maximum potential extent of entitlement over the continental shelf by a coastal State. This envelope forms the basis of a claim but it is still subject to spatial constraints in order to produce the delineation of the outer limits of the continental shelf.

The constraint rules are applicable pursuant to paragraphs 5 and 6, article 76 of the UNCLOS. Different from the alternative criteria that take the foot of

11 The paragraph 7 of article 76 of the UNCLOS determines that the State should draw the outer limit of its continental shelf, when this extends beyond the 200 maritime miles, "by straight lines not exceeding 60 nautical miles in length, connecting fixed points, defined by coordinates of latitude and longitude." 
slope as reference, the constraint criteria have two references, one related to the baselines from which the territorial sea width is measured, and the other related to the isobaths of 2,500 meters.

Considering these constraint rules, that are also connected by another inclusive disjunction, an extension claim cannot be made:

5. The fixed points comprising the line of the outer limits of the continental shelf on the sea-bed, drawn in accordance with paragraph 4 (a) (i) and (ii), either shall not exceed 350 nautical miles from the baselines from which the breadth of the territorial sea is measured or shall not exceed 100 nautical miles from the 2,500 metre isobath, which is a line connecting the depth of 2,500 metres.

As the same with the "formulae", the Guidelines present the interpretation of CLCS to the constraints:

2.1.8. The application of a negation over each of the two components connected by an inclusive disjunction implies that the compound is true so long as at least one of the constraints is satisfied. Thus, the outer limits of the continental shelf can extend either beyond a line delineated by reference to fixed points at a distance of 350 nautical miles from baselines from which the breadth of the territorial sea is measured, or beyond a line delineated by reference to fixed points at a distance of 100 nautical miles from the 2,500 metre isobath, but not both.

2.1.9. In practice, the use of an inclusive disjunction means that the outer envelope of the constraint lines identifies the breadth beyond which the outer limits of the continental shelf of a coastal State cannot extend. This outer envelope of the constraints does not provide per se the basis for entitlement to an extended continental shelf. It is solely a constraint placed over the envelope line produced by the formulae in order to delineate the outer limits of the continental shelf.

As a summary, the outer limit of the continental shelf is determined by the application of "formulae" and constraint rules. The use of a conjunction, in accordance with the Guidelines paragraphs 2.1.4 and 2.1.5 (CLCS 1999, 11),

implies that the full compound is true only so long as both components are true. Thus, at least one of the formulae and one of the constraints must be satisfied at all times [...] [and] means that the outer limit of the continental shelf is delineated by the inner envelope of two lines: the outer envelope of the formulae, and the outer envelope of the constraints.

The submission of extension of the continental shelf by a coastal State is based on these UNCLOS' criteria, but from the procedural point of view is guided by the Guidelines, which aim to 
providing direction to coastal States which intend to submit data and other material concerning the outer limits of continental shelf in areas where those limits extend beyond 200 nautical miles from the baselines from which the breadth of the territorial sea is measured. The Guidelines aim to clarify the scope and depth of admissible scientific and technical evidence to be examined by the Commission during its consideration of each submission for the purpose of making recommendations. (CLCS 1999, paragraph 1.2).

All the data and materials composing a Submission are the responsibility of the submitting State, thus their collection is guided by the Guidelines, insofar they determine such procedures, the technical and scientific rules and methodologies admitted by the CLCS.

In the case of the determination of the foot of slope, which will be of interest in determining the outer limits of the Brazilian platform in the Amazon Fan, in addition to the affirmative criteria of article 76 , paragraph 4 (a), (i) and (ii), the paragraph 4 (b) of the same article predicts a second system, the "evidence to the contrary" one:

In the absence of evidence to the contrary, the foot of the continental slope shall be determined as the point of maximum change in the gradient at its base.

This system of the evidence to the contrary, given the unique geological and geo-morphological features of the Amazon Fan, might deserve further considerations in a next study.

\section{Guidelines: legal nature}

The legal nature of the Guidelines, derived from the interpretation and nature of its rules, is reflected in an organism with sui generis characteristics in the international law: the CLCS is a formally legal organism, not jurisdictional, composed of non-jurists, but also a materially legal organism that has to base its recommendations on procedural and technical internal rules (such as the Guidelines), on the UNCLOS, and on the general international law, with highlight to the 1969 Vienna Convention on the Law of Treaties.

The Submission to the CLCS establishes a jurisdiction bond between the submitting State and the CLCS, based on the voluntary adhesion to a rule contained in the UNCLOS, which says that the extension of the continental shelf beyond the 200 nautical miles from the baselines through which the territorial sea width is measured is only legally legitimate in the conventional international law if submitted, and then recommended by the CLCS. This adhesion to the UNCLOS, however, must not be misunderstood nor interpreted as a legal adhesion to the Guidelines. 
Therefore, the coastal State shall not deposit, nor the UN Secretary-General shall accept the deposit of limits outlined pursuant of article 76 of the UNCLOS, without the due respect to the recommendations of the CLCS (Kunoy 2012, 114).

This is a legal jurisdiction bond of negative effect to the States that do not want the extension of their continental shelf, but can still legally oppose to the other States intentions through means other than the CLCS; or a positive effect bond to the coastal States that intend to have the natural extension of their territory towards the sea recognized, pursuant to article 76 , of the UNCLOS.

This opposition, though, has a limited exercise within the sphere of the CLCS $^{12}$. The recommendation grants an erga omnes effect only to the limits deposited ${ }^{13}$. Thus, as done by Australia, it is possible to deposit only the recommended limits (United Nations 2012), and, in thesis, reserving the nonrecommended limits to a future revised or new submission.

From the presented Submission, a positive bond is created, pursuant to paragraph 8, article 76 of the UNCLOS, so that "the limits of the shelf established by a coastal State on the basis of these recommendations shall be final and binding":

8. Information on the limits of the continental shelf beyond 200 nautical miles from the baselines from which the breadth of the territorial sea is measured shall be submitted by the coastal State to the Commission on the Limits of the Continental Shelf set up under Annex II on the basis of equitable geographical representation. The Commission shall make recommendations to coastal States on matters related to the establishment of the outer limits of their continental shelf. The limits of the shelf established by a coastal State on the basis of these recommendations shall be final and binding.

As article 8, Annex II of the UNCLOS provides for the possibility of a reviewed proposal or a new proposal in case of disagreement on the recommendations, the "final and binding" nature is only established on the limits recommended and deposited at the UN Secretary-General. There is, though, an expiration term of 10 years for the Proposals, which shall be observed pursuant to article 4, Annex II of the UNCLOS:

12 The United States have sent a letter to the UN Under-Secretary-General responsible for legal matters questioning the Summary of the Brazilian Submission, which had given publicity to all the UN members. In the letter, dated April 30, 2004, the United States requested the attention of the CLCS on the sediments thickness data and on the Vitória-Trindade Ridge. Retransmitted by the Secretary-General and received the CLCS letter, the president requested to the other members of the Commission to disregard the contents of the United States letter, remembering that both Annex II and the CLCS Procedures admit a single hypothesis for the communication by third-party States in the analysis of the proposals: in cases of dispute between States with opposed or adjacent coasts, or in cases of territories under maritime litigation or disputes (CLCS 2004, paragraphs 16 and 17; CLCS 2008c, article 46, paragraph 1).

13 Some countries such as Ireland and France decided to submit partial Submissions only about uncontroversial parts, reserving the future debate: "The partial OCS submission strategy adopted by some coastal States has seen submissions based on staggered partial claims, uncontested partial claims with future identified claims reserved, and uncontested partial claims with future unidentified claims reserved. The 'staggered claims' approach is best reflected in the strategies adopted to date by Ireland and France." (Rothwell 2008, 204). 
Where a coastal State intends to establish, in accordance with article 76, the outer limits of its continental shelf beyond 200 nautical miles, it shall submit particulars of such limits to the Commission along with supporting scientific and technical data as soon as possible but in any case within 10 years of the entry into force of this Convention for that State. The coastal State shall at the same time give the names of any Commission members who have provided it with scientific and technical advice.

In view of a total or partial negative recommendation, considering the expiring term of 10 years, and the "reasonable term" mentioned in article 8 , Annex II of the UNCLOS, there are then a few issues: a) what characterizes the new Submission?; b) what is the reasonable term for a revised Submission?; and c) is the admissibility judgment, pursuant to article 34 of the CLCS Rules of Procedure (CLCS 2008c, 8), of the request of reconsidering a submission (adopted or rejected submission) legally valid? Which Subcommission will appraise a new or a revised Submission? The same prior one, a new Subcommission or a subsidiary uniformizing organism? There are relevant issues for the appraisal of alternatives for Brazil on the Recommendation received from CLCS, as we will see further.

For now, we should consider that the possibility of new or revised submission can be regarded as an exhaust valve for the future application of new technologies, techniques and scientific theses, since it is a principle in the international environmental law, for instance, to establish a scientific truth based on the best technology available ${ }^{14}$, leaving the doors open to the evolution of knowledge. However, this is viable only if the interpretation of the Guidelines on the proposals follows the same principle, also from the viewpoint of uniformization.

The Guidelines clearly show the CLCS concern to standardize the process of preparing new technical and scientific evidences (CLCS 1999, 7-8):

1.4. The Commission designed these Guidelines with a view to ensuring an uniform and extended State practice during the preparation of scientific and technical evidence submitted by coastal States. The Commission is aware that there might be other scientific and technical methodologies used by States to implement the provisions of article 76 to prepare a submission which may not be covered in this document. These Guidelines are not intended to exhaust the full range of possible methodologies contemplated by States. Whereas

14 The concept of the best available technology belongs to the environmental law, and in regard to the law of the sea it finds fundament in the protection of the marine environment. The concept is expressly mentioned in the Convention for the Marine Environment of the Northeastern Atlantic (Convention for the Protection... 1992). The concept of "best geological and geophysical evidence available" is mentioned in the Guidelines in paragraphs 6.3.1 and 6.1.10. The last one states that: "The Convention does not prescribe the application of a specific scientific methodology to define the location of the foot of the continental slope when evidence to the contrary to the general rule is invoked. The Commission interprets this provision as an opportunity for coastal States to use the best geological and geophysical evidence available to them to locate the foot of the continental slope at its base when the geomorphological evidence given by the maximum change in the gradient as a general rule does not or can not locate reliably the foot of the continental slope." (CLCS 1999, 44). 
several scientific and technical avenues are available to develop an admissible body of evidence which may conform equally with all the relevant provisions contained in the Convention, the Commission has endeavored to emphasize those which might minimize costs and result in optimization of existing information and resources.

1.6. [...] These Guidelines are not aimed to describing in detail the scientific theories or precise technical methodologies involved in each discipline.

The controversy is that the process uniformization finds not equivalent in the decision uniformization, i.e. in the recommendations. The formal and objective uniformization of the procedures is not necessarily reflected in a material and subjective uniformization of the judge interpretation.

If the UNCLOS represents a legal system of the sea, if the Annex II of the UNCLOS establishes a voluntary jurisdictional procedure (formal and material) with erga omnes effects, and if the CLCS Guidelines defend the uniformization of submission processes, the procedure of analysis of recommendations by CLCS should also be changed to provide the uniformization expected by applicant States, as a measure of legal and political safety of the procedure as a whole. An evidence of this insecurity, without any judgment of value, is revealed by the inconformity of the United Kingdom (United Kingdom 2011) in regard to the recommendations related to the Ascension Island (CLCS 2008a).

Thus, the main alteration should take place in the revision proposals, whose re-analysis should not be done by the original Subcommission, but rather by a different Subcommission (or composed of different members), perhaps an organism or a procedure of uniformization ${ }^{15}$, whose creation should be urgently evaluated. As we see, the CLCS is not immune to criticism.

\section{Criticism to CLCS}

Although the UNCLOS and the Guidelines are technical-legal diplomas that, in view of their nature, should grant a certain degree of safety, surety and predictability as for the scientific criteria and methodologies adopted in the recommendations, there are growing controversies about the CLCS work.

15 According to article 6 (2) of the UNCLOS Annex II, the approval of a Recommendation requires two thirds of the present and voting members, meaning that 14 of the 21 members should approve it. However, 7 CLCS members formed the Subcommission that has appraised the Brazilian request, and 1 member is impeded for being Brazilian [Rear-Admiral (ret.) Jair Alberto Ribas Marques]. Considering that all the 21 members are present, the voting members will only be 20 . Then, hypothetically, if 7 members of the Subcommission keep their votes, it is mathematically impossible to reach the two thirds (14 votes) necessary to approve, or to admit a new proposal or a revised one, since there will only be 13 remaining members, even if they vote unanimously. The possible observation of absent members only stresses this evidence. 
Under the legal viewpoint, Kunoy et al. (2010, 359-361), Serdy $(2011,364)$, Subedi $(2011,421)$ and Kunoy $(2012,116)$ present very pertinent criticism to the CLCS in regard to two points:

a) The illegitimate exercise by CLCS of the function of interpreting the UNCLOS, which Serdy (2011) calls the "legislative function"; and

b) About the legal nature of the Guidelines, which are regarded as not legally binding.

As scientific articles of common authors, the following excerpt by Kunoy $(2012,116)$ is a good reflection of the common fundament of the legal criticism about the works of CLCS in this regard:

The Commission has not been vested with powers to adopt legal instruments that would be binding upon states parties to the Convention and the Scientific and Technical Guidelines 44 ("the Guidelines") are, per se, not legally binding on state parties. It is true that subsequent agreements may "have a bearing on the juridical situation of the parties and on the rights that each one of [the state parties] could properly claim". Yet, only agreements "between the parties" may constitute subsequent agreements within the meaning of Article 31(3) (a) of the Vienna Convention on the Law of Treaties ("the Vienna Convention"). The Commission cannot, for evident reasons, be a state party to the Convention and therefore the Guidelines cannot constitute a subsequent agreement within the meaning of Article 31(3)(a) of the Vienna Convention.

Under the technical viewpoint, which is not far apart from the legal one for being based on it to be valid and effective, the CLCS is facing criticism about the interpretation of the Guidelines.

For instance, in the case of the Australian Submission, the questioning is related to the interpretation about the application of the restrictive criterion of the 2,500 $\mathrm{m}$ isobath (Kunoy 2010, 358; CLCS 2008b).

In the case of Brazil, which had four areas not recommended by the CLCSthe Amazon Fan among them-, the criticism is related to the interpretation given by the CLCS to the bathymetric, geological and seismic data submitted by Brazil for the determination of the foot of slope.

In a universe of 106 submissions before the CLCS, of which 61 are definitive, and another 45 being preliminary, the potential for controversies is unlimited, both regarding the quantitative and qualitative aspects of such submissions, from the legal or technical (i.e. geodesy, geology, geophysics or hydrography) viewpoint.

Quantitatively, the 106 proposals of coastal States for the extension of their continental shelf imply, by exclusion, the advance on what was previously regarded 
as Area, thus on the common heritage of mankind (article 136 of the UNCLOS), i.e. of all the States.

Qualitatively, the potential for controversies is of the essence of the theme, which touch historical and Law fundaments, such as the sovereignty on marine waters, seabed and subsoil, a dispute that goes back as far as the Ancient times (Rangel 2008; Reis and Almeida 2012).

\section{The controversies about the Amazon Fan: the recommendations from the CLCS}

The Main Body of the Brazilian Submission before the CLCS remains confidential, as all the other main bodies already submitted to the CLCS to date, thus, until they are disclosed to the public, the main instrument of analysis of the controversies between the CLCS and Brazil is based on summaries: the executive summary of Brazil and the summary of CLCS recommendations.

In the case of the Amazon Fan, the controversies between Brazil and the CLCS is about the location of the foot of slope, as the result of the controvert interpretation about the bathymetric, geological, potential (gravity and magnetometrical) and seismic data submitted by Brazil. The methodology of data processing and collection followed the technique usually employed in researches for academic and scientific purposes, and in the oil industry. However, the interpretative and methodological controversies between the CLCS and Brazil, which should be guided and solved by the Guidelines, were not harmonized.

According to the CLCS Subcommission (composed of 7 experts) that analyzed the Brazilian Submission, the analyses produced by Brazil have identified 7 points in the foot of slope located in the transition zone between the Middle Fan and the Lower Fan of the Amazon (Figure 1), in depths between 3,600 $\mathrm{m}$ and 4,100 m, in which there is a small change in the gradient (CLCS 2011, paragraph 29). 


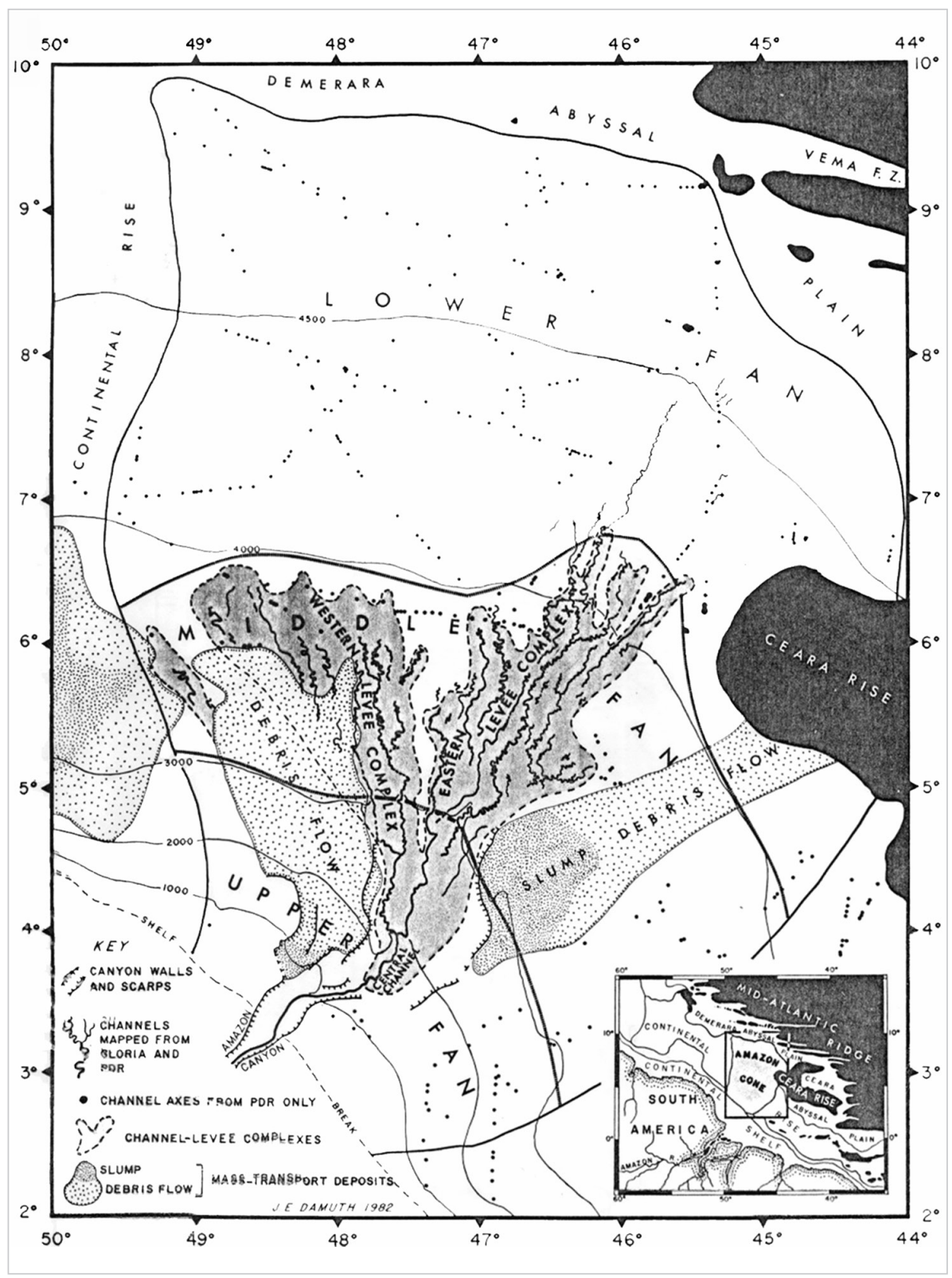

Figure 1. Amazon Fan described by Damuth and Flood (1987).

Upon examining the Brazilian data, we see that the analysis of the Subcommission was that the foot of slope should be defined in the location of the major regional change of the gradient, in approximate depths of 2,600 m 
and 3,400 m, coinciding with the change in depositional pattern (of sediments), more similar to a continental rise $^{16}$.

The difference of the approximate depths of the foot of slope shows the tone of the controversy between Brazil and the CLCS, which we will further explore.

As we can soon notice, the major challenge of this study in presenting the controversy about the Amazon Fan is its interdisciplinary nature, especially Law and Geology: slope, continental elevation, change of gradient, bathymetric profiles and seismic data are not routine terms for the jurist or the political scientist or an internationalist, although they are terms related to the Law of the Sea; although being formally a legal instrument, the UNCLOS requires technical instruments, such as the Guidelines (CLCS 1999), whose legally binding nature is controversial (Figure 2).

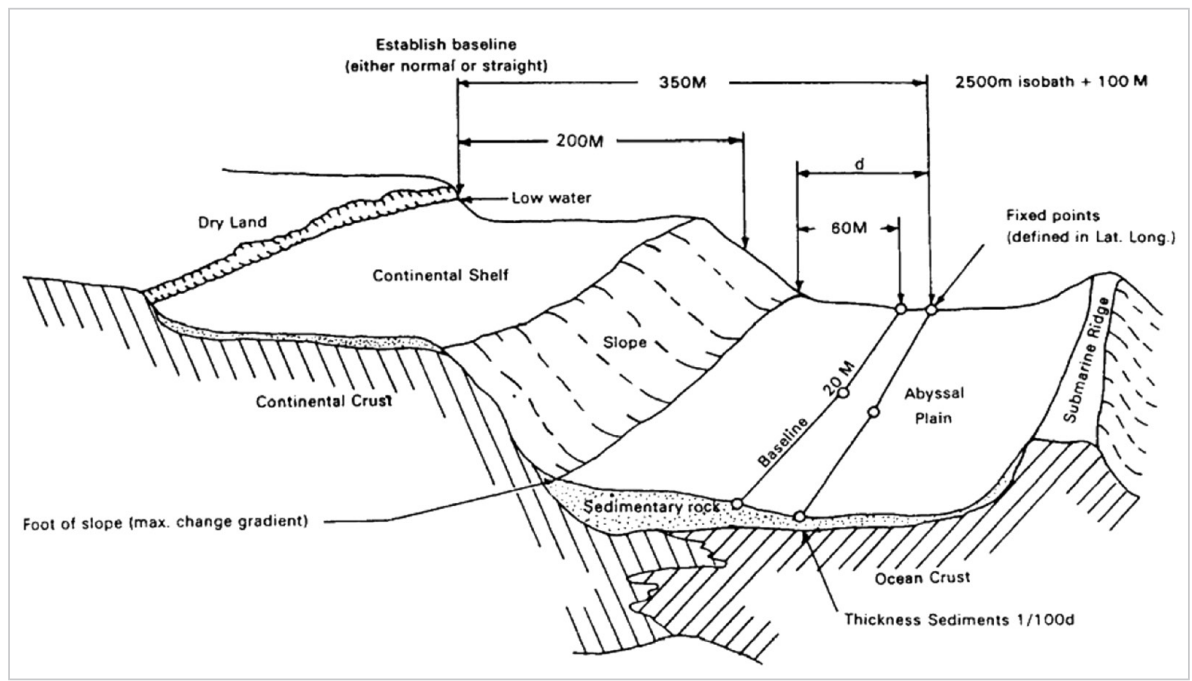

Figure 2. Submarine relief and its legal limits.

Source: International Hydrographic Organization (2006).

The aspect of the interdisciplinary nature is noteworthy, in view of having given raise to the doubt about the need of "translating" or "explaining" some terms of geology, for instance, for a more laic language, closer to the international Law and international relations. On the other hand, this study intends to establish a bridge between law and international relations and the sciences of the sea (i.e. geodesy, geology, geophysics or hydrography), which has the law at the margin of their concepts. Thus, the translation of the concepts of the sciences of the sea to the law did not seem methodologically appropriate to us, although we do that on a punctual and exceptional basis, especially in a vertical and deep study as

16 This point is cleared by paragraph 6.2.2 of the Guidelines (CLCS 1999, 45). 
this one, for which the prior pursuit or knowledge of basic geology concepts, for instance, is inherent to the ongoing process of scientific research, the effective interdisciplinary nature.

Thus, the understanding of this section requires a very basic knowledge about the definition of "fan," as that format at the bank and along the Amazon river mouth, as that conic format resulting from the discharge of sediments by marine currents and by the Amazon river itself towards the deep sea, as shown in Figure 1, of Damuth and Flood (1987), which identifies the Amazon Fan as the third biggest deep sea fan in the world.

The shape of the fan and its thickness and extension result from various geological, geophysical and hydrographic factors that, according to the LEPLAC analysis, make the Amazon Fan unique and different from the other formations observed in the Brazilian bank.

Technical-legal criteria, the "test of appurtenance" and the foot of slope

The Brazilian Submission for the extension of the continental shelf in the Amazon Fan is based on the "formulae" of article 76, paragraph 4, items (i) and (ii) (thickness of sedimentary rocks of at least $1 \%$ of the shortest distance between such point and the foot of slope, or the limit of 60 nautical miles from the foot of slope) and the constraint rule of paragraph 5 of the same article (350 nautical miles from the baselines from which the breadth of the territorial sea is measured), in addition to respecting the maritime frontier between Brazil and the French Guiana, fixed in the 1981 Treaty of Paris.

As we have said, the first evaluation of a Submission is the "test of appurtenance," i.e. whether the Amazon Fan can be considered a natural extension of the Brazilian territory. The test is a "requirement of admissibility" for the appraisal of the Submission, and was affirmative in the case of Brazil, which means that the Submission was appraised in a qualitative, technical, and scientific manner, with the purpose of determining the limit points based on the "formulae" and constraint rules of paragraphs 4 and 5, respectively, of article 76 of the UNCLOS.

The second evaluation about the Amazon Fan was the identification of the points composing the foot of slope: the controversies between Brazil and the Subcommission are established.

It is possible to summarize such controversies in a technical-scientific debate about the unique features of the Amazon Fan, whose analysis of data and material, pursuant to the Brazilian Submission, require the integration of knowledge. In order to summarize and more precisely define such controversies, it is helpful to check some excerpts highlighted by CLCS itself in the recommendations, as part of the manifestation of Brazil in the debates, along with the analysis of the Submission (CLCS 2011, paragraphs 33-34): 
33. ...The Brazilian submission considers the Upper and Middle Fan as analogous to a continental slope and the lower fan analogous to a continental rise, therefore placing the base of the continental slope at the Distal end of the Middle Fan, coinciding with the lobe deposition of the Channel levee systems.

34. This understanding is based on: the similarities between erosive and depositional processes; the continuous slope downwards without a regional break; and the continuous channel levee systems down to the boundary with the Lower Fan.

The continuous slope of the Amazonas Fan cannot be compared to the normal passive margin described by Heezen et al. (1959);

It is difficult to identify the region of the base of the continental slope and place of the FOS in continuous slope of a unique feature such as the Amazonas Fan;

In order to provide an analogy with a normal continental slope and rise, it considered carefully the physiography and the geological processes of erosion and deposition in the Amazonas Fan.

The controversy is established about the analysis of bathymetric and seismic data provided by Brazil, according to different geological, geophysical and geomorphological criteria.

Brazil has identified that the foot of slope is between the Middle Fan and the Lower Fan of the Amazon (Figure 1), in a depth between 3,600 $\mathrm{m}$ and 4,100 m, in which very small change in gradient occurs (CLCS 2011, paragraph 29). On the other hand, the Subcommission has identified the foot of slope in the region where a maximum change in gradient occurs, according to its interpretation, in approximate depths of 2,600 $\mathrm{m}$ and 3,400 $\mathrm{m}$, coinciding with the regional change of the (sediments) deposition pattern, with characteristics of a continental elevation:

37. The Subcommission found that the most significant regional change in the gradient along the fan takes place beneath the upper-middle fan transition zone at depths between 2,600 $\mathrm{m}$ and 3,400 $\mathrm{m}$ based on its analysis of the bathymetric data in agreement with the available international scientific literature. From a morphological perspective, no other region throughout the entire fan offer with greater clarity the location of the base of the slope, which merges with a conventional passive margin base of the continental slope towards its northern and southern ends.

[...]

41. There are different views in the international scientific literature in relation to the classification of certain parts of deep sea fans according to the conventional components in which continental margins are subdivided: shelf, slope and rise. For example, while Babonneau et al. (2002) consider the upper fan as analogous to a continental slope and the middle and lower fans analogous to a rise, Curray et al. (2003) consider the upper, middle and lower 
fan as equivalent to a continental rise in a different geographical instance. The Subcommission considers the Amazonas upper fan to be analogous to a continental slope (although with a smaller gradient), and the middle and lower fans to be analogous to a continental rise based on all the morphologic data and supplemented by the geological and geophysical data contained in the Submission and the information available in the international scientific literature.

42. The methodology described in the Submission to determine the base and the foot of the continental slope throughout its entire Submission is purportedly based on morphological criteria and supplemented by geological and geophysical data. The approach apparently advocated by the delegation of Brazil in the Northern and Amazonas Fan Region during its latest consultations with the Subcommission would appear to emphasize a geological argument based on some but not all sedimentary processes prevailing over and above the main results found based on morphology and other supplemental geological and geophysical information. This scenario suggested the investigation of this part of the Submission under the provision of evidence to the contrary to the general rule contained in article 76 . But when this approach was examined with the existing information in the Submission, it became clear to the Subcommission that the same location for the base of the continental slope along the profiles listed in Table 1 would be found.

As the result of the foot of slope controversy, the Subcommission could not define the outer limit of the continental shelf beyond the 200 nautical miles in the Amazon Fan:

60. As a result of the remaining uncertainty in the determination of the exact locations of the foot of the continental slope in the base of the continental slope regions identified by the Subcommission and the absence of geodetic and seismic information needed to define new formulae lines, the Subcommission was unable to consider the outer limit of the continental shelf beyond 200 nautical miles in the Northern and Amazonas Fan Region.

The summary of recommendations completes the analyses of the continental shelf extension in the Amazon Fan as follows, using a mandatory and illegal wording by considering the legal nature of a CLCS's recommendation:

61. The Commission recommends to Brazil to make a revised or new Submission in respect of the outer limits of its continental shelf beyond 200 nautical miles in the Northern and Amazonas Fan Region.

62. The Commission recommends that the foot of the continental slope be determined in a new or revised Submission within the base of the continental slope in agreement with the methodologies applied and results described by the Commission in these Recommendations. 
63. The Commission recommends that Brazil give consideration to the findings and implications outlined above with respect to the definition of sediment thickness points in a new or revised Submission, and to the concerns raised with respect to some velocity analysis and seismic interpretation matters in the northern part of the Northern and Amazonas Fan Region.

As there is no appeal organism in the CLCS, article 8 of Annex II of the UNCLOS only predicts two alternatives that should be performed in "reasonable time": the presentation of a new submission or a revised submission.

\section{Alternatives: new or revised submission?}

As they are excluding alternatives, with complex legal, political, and strategic implications in various fields and activities that Brazil intends to regulate about its (extended) continental shelf, this section has no intention of depleting the debate, but only of launching it to the reflection of Brazilian academia.

In view of the partial recommendation about the Brazilian Submission, the main issue formulated to this section appears: will Brazil make a new Submission or a revised one? From these issues, other issues already raised in this study are derived: a) What characterizes the new Submission? b) What is the reasonable term for a revised Submission? c) Is the admissibility judgment, pursuant to article 34 of the CLCS Procedural Rules (CLCS 2008c, 13) of the request of reconsidering a proposal (adopted or rejected proposal) legally valid? Which Subcommission will appraise a new or a revised Submission? The same prior proposal, a new Subcommission or a subsidiary uniformizing organism?

The distinction between a new and a revised Submission is determined by the "subject-matter" or "the cause of action" criteria declined by the coastal State in its Submission. The CLCS has no power to deny a revised Submission based on its procedural rules nor in any other rule, including the UNCLOS and the international general law. This is because only the States have the original and sovereign power to interpret the UNCLOS in accordance with article 31, paragraph 3 (a) of the 1969 Vienna Convention.

The wording of article 8 of the UNCLOS Annex II allows the coastal State, on disagreeing with the recommendations, to submit to the CLCS, in a reasonable time, a revised or new proposal.

In a restricted interpretation, if revised, the Submission should have as scope the limits regarding the area already appraised by the CLCS. This means, since the UNCLOS does not present impediment, that some limits, even if already recommended, but also made definitive and obligatory by the deposit before the UN Secretary-General, can be updated. By expanding this scenario it is also possible to present a revised Submission on areas already recommended by CLCS, but not yet deposited, since new data are available by application of the legal 
principle of the "best technology available" and "best geological and geophysical evidence available."

Nothing forbids, equally based on the UNCLOS, that revised Submissions be partially submitted, area by area, as done by Russia, Indonesia, Mexico, and France. There is also no restriction in adding new areas to a revised submission since those added areas and their limits are contiguous to the non-recommended limits. If they are contiguous, they are part of the same natural prolongation of landmass, of the same polygon of coordinates, and may be added by the natural application of the principles above.

The difference nature of a new Submission and a revised one has also an impact on the procedural aspect of a Submission: a new Submission is placed in the end of a long line of definitive and other preliminary submissions; a revised one does not, as was the case of the Russian revised Submission about the sea of Okhotsk in 2013.

This lack of clarity, or perhaps a more extensive interpretation of that article 8, considering the whole UNCLOS and not only the restrictive particularity of the CLCS and its rules of procedure (CLCS 2008c), was evidenced in the procedure of analysis of the Brazilian Submission, where the principle of allowing the supplement and even the rectification of the material was established, because, according to the UN Under-Secretary-General for Legal Matters Nicholas Michel, there is nothing in the UNCLOS that excludes the right of the State to submit revised data in the course of an appraisal (CLCS 2005, 12-13).

As we have seen, the CLCS recommendations for Brazil have a wording that extrapolates a technical guidance nature, a mandatory and illegal wording, approximating the CLCS to a de facto, but not de jure, jurisdictional organism.

Thus, in a restrictive interpretation supported in the CLCS practice related to the illegitimate exercise of the jurisdictional and legislative power, if the coastal State decides to follow the CLCS guidance on disagreeing limits, it will submit a revised submission, by adapting the original submission to the recommendations, which in our opinion is a material legal misrepresentation of the CLCS functions.

Following the same restrictive thesis, if it decides to oppose the recommendations, invoking the technical aspects of its original Submission, it should propose a new Submission.

On the other hand, in the two hypothesis, but interpreting the CLCS practice and the legal governing rules in an extensive manner as done by Michell (CLCS 2005, 12), the coastal State might add data, material, and information, thus invalidating the legal distinction as for the contents of the submission (new or revised), only stating its formal nature related to the procedural rules: the place in the "line." The "reasonable time" for one or another submission in view of the disagreement on a recommendation seems to be the same of the submission: 10 years. 
Concerning the analysis of admissibility about a new or revised submission, in the event of a disagreed recommendation, article 34 of the CLCS Rules of Procedure (CLCS 2008c, 13) binds it to a two-thirds majority quorum among the present and voting members. This bond seems illegal to us, insofar as the sovereignty right exercise provided for in article 76 of the UNCLOS cannot be limited by an internal CLCS rule, the same way as the internal rule itself does not estipulate the judgment of admissibility for original Submissions.

In the case of a revised Submission, perhaps the key question is the following (already mentioned in this study): will it be appraised by the same Subcommission? It is noteworthy that the answer to this question is not clear for a new Submission, because there is no restriction in the CLCS Rules of Procedures (CLCS 2008c), in special among the rules that determine the composition of the Subcommissions, such as article 42 (CLCS 2008c, 14). Then, what is the relevance of the question?

The relevance lays on the technical-scientific uniformity that the recommendations should reflect by force of the provisions of the Guidelines. By definition and principle, the reasons for the decision should not subjectively vary from one Subcommission to the other, undermining the pursuance for the legal safety and the peaceful settlement of controversies, which crisscross the whole UN system, reflected on the special rule in the UNCLOS article 76, and specially in article 2, paragraph 3, of the United Nations Chart.

Therefore, the Subcommission or the same members cannot analyze a revised or new Submission of a coastal State with the same object of proposal already recommended, under penalty of making the methodology, the criteria, and the interpretation of the expert or of the Subcommission on the Guidelines and on the limits that, paradoxically, have not been enhanced, definitive and mandatory. Furthermore, due to the confidentiality of the proposals, the international scientific literature shows much varied understandings of Subcommissions in the application of the Guidelines, in special in situations of contrary evidence and identification of sedimentary processes.

The solution for a uniformization is relatively simple, and is supported by the CLCS Rules of Procedure, in article 43 (CLCS 2008c, 15), which allows the creation of subsidiary organisms to perform the functions, the main one for the uniformization, surety, and technical and scientific safety of aspects of geology, hydrography and geophysics, including legal aspects, in the examination of data and materials in the presentation of recommendations (UNCLOS, Annex II, article 3, paragraph 1). Such aspects can only be satisfactorily met by the creation of an organism or Subcommission for uniformization or revision. The first step could be simple: a Subcommission could simply meet frequently with other Subcommissions for exchange of experience and technical talks.

Obviously, the creation of a subsidiary organism increases, from the practical point of view, the overload on the current 21 experts, who will have to analyzed 106 Submissions, among preliminary and definitive ones, thus an increase of the 
number of the CLCS experts should be considered, which, on one hand, increases the risk of subjectivity, but on the other hand is compensated by the uniformization, thus solving the base legal issue on the legitimacy of the recommendation, which make definitive and mandatory the recommended limits after being deposited. The Brazilian submission concerning the Amazon Fan should be considered under this approach.

\section{Final considerations}

The potential of divergences and conflicts about the CLCS recommendations is revealed at each published recommendation, especially because of the lack of uniformity as for the interpretation of the Guidelines in each Subcommission, creating uncertainty, insecurity, and unpredictability about an extremely sensitive topic, which addresses the sovereignty rights on the wealth of the bed and the subsoil composing the continental shelf. Along with the Submissions, mining exploitation potential is identified, which, based on the UNCLOS legal definition, is no longer subjected to the legal system of the marine depth exploitation, including the Area (articles 136 to 155), the competences and the activities of the International Seabed Authority and the Enterprise (articles 156 to 171), the Annex III (Basic Conditions of Prospecting, Exploration and Exploitation), and the Annex IV (Statute of the Enterprise).

Shortly, Brazil possibly will submit a new or a revised Submission about the four non-conclusive areas according to CLCS, the Amazon Fan among them, which are the object of this brief study. Technical and scientific support, resulting from new collected data combined with new processing techniques, might possibly guide that the limits so far proposed, in particular for the Amazon Fan, could be displaced to positions further towards the sea.

As we have noticed, this is an issue marked by the interdisciplinary nature among geology, geophysics and hydrography with the law, which has a fundamental role as much as of those sciences in the interpretation of the UNCLOS, the Guidelines and the recommendations. In fact, the law should perform the important role since the formulation of the Submission, since the product of the CLCS appraisal is a legal document by nature, although the CLCS has no jurists, which perhaps explain the mistakably mandatory tone of the conclusions and recommendations it is publishing. The submission before the CLCS is the conventional legal condition to the extension of the continental shelf, but the recommendation is not mandatory, because the CLCS has no competence to legally interpret the UNCLOS, nor to legislate.

The divergences about the recommendations, reported by the international literature, suggest the need to expand the CPLC and review its functions, in particular by the creation of a uniformization procedure or organism, since the revised proposals will be added to those awaiting analyses. It is necessary to 
strengthen the role of the CLCS, by strengthening the legal instruments that consolidate its legitimacy, otherwise the following can be questioned: if the continental shelf is an ipso facto and ab initio natural extension of the coastal territory, why submit it to the CLCS? There is the potential risk of questioning the legitimacy of the CLCS and of the contra legem acts that need to be considered if the CLCS does not meet the technical-legal expectations of the coastal States.

\section{Bibliographic references}

BRAZIL. Decree no. 1,530, of 22 June 1995. Declares the entry into force for Brazil of the United Nations Convention on the Law of the Sea. Official Gazette 23 June 1995, p. 9,199.

DAMUTH, John E; FLOOD, Roger D. (1987). Quantitative characteristics of sinuous distributary channels on the Amazon Deep-Sea Fan. Geological Society of America Bulletin, v. 98, p. 728-738, Junho 1987. Available at: http://www.ig.utexas.edu/people/staff/damuth/ reprints/amazon_quantitative.pdf. Accessed 9 February 2014.

JECK, Izabel King; ALBERONI, Ana Angelica Ligiero; TORRES, Luiz Carlos. (2012). The Definition of the Base of Slope on the Amazon Sea Fan. Paper presented in the Session 2 of the 7th ABLOS Conference (Advisory Board on the Law of the Sea) in 2012. Available at: http://www.iho.int/mtg_docs/com_wg/ABLOS/ABLOS_Conf7/Papers.zip. Accessed 03 February 2014.

KUNOY, Bjørn. (2012). The Terms of Reference of the Commission on the Limits of the Continental Shelf: A Creeping Legal Mandate. Leiden Journal of International Law, 2012, 25, p. 109-130. doi:10.1017/S0922156511000604.

KUNOY, Bjørn; HEINESEN, Martin V.; MØRK, Finn. (2010). Appraisal of Applicable Depth Constraint for the Purpose of Establishing the Outer Limits of the Continental Shelf. Ocean Development \& International Law, 41, 2010, p. 357-379. DOI: 10.1080/00908320.2010.521035.

CLCS. Commission on the Limits of Continental Shelf. (2011). Summary of the recommendations prepared by the Subcommission established by the Commission on the Limits of the Continental Shelf to consider the Submission made by Brazil. Available at: http://www.un.org/depts/los/clcs_new/submissions_files/bra04/Summary_Recommendations_ Brazil.pdf. Accessed 09 February 2014.

(2008a). Summary of Recommendations of the Commission on the Limits of the Continental Shelf in regard to the Submission made by the United Kingdom of Great Britain and Northern Ireland in respect of Ascension Island on 9 May 2008. Available at: http://www.un.org/depts/los/clcs_new/submissions_files/gbr08/gbr_asc_isl_rec_summ.pdf. Accessed 27 February 2014.

. (2008b). Recommendations of the Commission on the limits of The continental shelf (CLCS) in regard to the submission made by Australia on 15 November 2004. Available at [http://www.un.org/depts/los/clcs_new/submissions_files/aus04/Aus_Recommendations_ FINAL.pdf]. Accessed 09 February 2014.

. (2008c). Rules of Procedure of the Commission on the Limits of the Continental Shelf. Document no. CLCS/40/Rev.1 of 14 April 2008. Available at [http://daccess-dds-ny. un.org/doc/UNDOC/GEN/N08/309/23/PDF/N0830923.pdf?OpenElement]. Accessed 09 February 2014. 
(2005). Letter and legal opinion, dated 25 August 2005 from the Legal Counsel, Under-Secretary-General of the United Nations for Legal Affairs, addressed to the Chairman of the Commission on the Limits of the Continental Shelf. Document no. CLCS/46 of 07 September 2005. Available at: http://daccess-dds-ny.un.org/doc/UNDOC/GEN/ N05/482/97/PDF/N0548297.pdf?OpenElement. Accessed 25 February 2014.

(2004). Statement by the Chairman of the Commission on the Limits of the Continental Shelf on the progress of work in the Commission. Document no. CLCS/42 of 14 September 2004. Available at: http://daccess-dds-ny.un.org/doc/UNDOC/GEN/N05/482/97/ PDF/N0548297.pdf?OpenElement. Accessed 18 January 2014.

(1999). Scientific and Technical Guidelines of the Commission on The Limits of the Continental Shelf. Document no. CLCS/11 of 13 May 1999. Revised by CLCS/11/ Add.1 (03 September 1999); CLCS/11/Add.1/Corr.1 (19 November 1999) and CLCS/11/ Corr.1 (24 February 2000). Available at: http://www.un.org/depts/los/clcs_new/documents/ Guidelines/CLCS_11.htm. Accessed 03 February 2014.

CONVENTION FOR THE PROTECTION OF THE MARINE ENVIRONMENT OF THE NORTH-EAST ATLANTIC (1992). Paris 22 September 1992. Available at: http://www.ospar.org/html_documents/ospar/html/ospar_convention_e_updated_text_2007.pdf. Accessed 25 February 2014.

IBGE; Marinha do Brasil. (2011). Atlas Geográfico de Zonas Costeiras e Oceânicas do Brasil. 2011. Available at: https://www.mar.mil.br/secirm/p-atlas.html. Accessed 03 February 2014.

MORE, Rodrigo Fernandes. (2012). Quando cangurus voarem: a declaração unilateral brasileira sobre direito de pesquisa além dos limites da plataforma continental - 2010. Revista de Direito Internacional, Brasília, v. 9, n. 1, jan/jun 2012, p. 59-68.

RANGEL, Vicente Marotta. (2008). Direito do mar e solução de controvérsias: das origens até o século XIX. In: Casella, Paulo Borba... [et al] (orgs). Direito internacional, humanismo e globalidade: Guido Fernando Silva Soares: Amicorum Discipulorum Liber, São Paulo: Atlas, 2008.

REIS, Reginaldo Gomes Garcia dos; ALMEIDA, Francisco Eduardo Alves de. (2012). A luta pelo domínio do mar na história. In: MORE, Rodrigo Fernandes; BARBOSA JÚNIOR, Ilques (Org.). Amazônia Azul: política, estratégia e direito para o oceano do Brasil. Rio de Janeiro: SaG. Serv., Femar, 2012, p. 23-54.

UNITED KINGDOM. Note no. 08/11 of the Permanent Mission of United Kingdom of Great Britain and Nothern Ireland. Dated 11 January 2011. Available at: http://www.un.org/depts/ los/clcs_new/submissions_files/gbr08/gbr_nv_11jan2011.pdf. Accessed 27 February 2014.

ROTHWELL, Donald R. (2008). Issues and Strategies for Outer Continental Shelf Claims. The International Journal of Marine and Coastal Law 23, 2008, p. 185-211.

SERDY, Andrew. (2011). The Commission on the Limits of the Continental Shelf and its Disturbing Propensity to Legislate. In: The International Journal of Marine and Coastal Law 26, 2011, p. 355-383.

SILVA, Alexandre Pereira. (2013). O novo pleito brasileiro no mar: a plataforma continental estendida e o Projeto Amazônia Azul. Rev. Bras. Polít. Int. 56 (1), 2013, p. 104-121.

SUBEDI, Surya P. (2011). Problems and Prospects for the Commission on the Limits of the Continental Shelf in Dealing with Submissions by Coastal States in Relation to the Ocean Territory Beyond 200 Nautical Miles. In: The International Journal of Marine and Coastal Law 26 (2011), p. 413-431. 
UNCLOS. The United Nations Convention on the Law of the Sea of 10 December 1982. UN Official version in English available at http:/www.un.org/depts/los/convention_agreements/ texts/unclos/UNCLOS-TOC.htm. Accessed 02 March 2014.

Fifth Meeting of the Parties (1996). Document no. SPLOS/CLCS/INF/1, of 10 June 1996. Available at: https://www.un.org/depts/los/clcs_new/commission_documents.htm. Acessed 03 March 2014.

UNITED NATIONS. Circular Communications from the Division for Ocean Affairs and the Law of the Sea Office of Legal Affairs. Maritime Zone Notification MZN.92.2012.LOS. Deposited by Australia (2012). Available at: https://www.un.org/depts/los/LEGISLATIONANDTREATIES/ PDFFILES/mzn_s/mzn92ef.pdf. Accessed 25 February 2014.

\title{
Websites
}

SECRETARIAT OF THE INTERMINISTERIAL COMMISSION ON THE RESOURCES OF THE SEA. Available at: www.mar.mil.br/secirm/. Accessed 10 March 2014.

UNITED NATIONS. Division for the Ocean Affairs. Available at: http:/www.un.org/depts/ los/clcs_new/commission_submissions.htm. Accessed 25 February 2014.

Submitted March 10, 2014 Approved March 14, 2014

\begin{abstract}
In 2004, Brazil submitted to the Commission on the Limits of the Continental Shelf (CLCS) a Submission for the outer limit of the Brazilian continental shelf for its extension beyond the limits of 200 nautical miles. In 2007, the CLCS presented its recommendations, however it did not recommend four areas proposed by Brazil, the Amazon Fan among them. The objective of this study is to present the main legal and technical aspects of the controversy about the Amazon Fan, in order to evaluate some alternatives for a future submission, new or revised.
\end{abstract}

Keywords: Amazon Fan; CLCS; continental shelf; foot of slope; outer limit.

\section{Resumo}

Em 2004, o Brasil submeteu à Comissão de Limites da Plataforma Continental (CLPC) uma proposta para o limite exterior da plataforma continental brasileira para extensão além das 200 milhas náuticas. Em 2007, a CLPC apresentou suas recomendações; no entanto, não recomendou quatro áreas propostas pelo Brasil, entre elas o Cone do Amazonas. O objetivo deste estudo é apresentar os principais aspectos legais e técnicos da controvérsia sobre o Cone do Amazonas a fim de avaliar algumas alternativas para uma futura submissão, nova ou revisada.

Palavras-chave: Cone do Amazonas; CLPC; plataforma continental; pé do talude; limite exterior. 